\title{
Evidence of multiple paternity and cooperative parental care in the so called monogamous silver arowana Osteoglossum bicirrhosum (Osteoglossiformes: Osteoglossidae)
}

\author{
Júlia Tovar Verba ${ }^{1,3}$, José Gurgel Rabello Neto², Jansen Zuanon ${ }^{1}$ and Izeni Farias ${ }^{3}$
}

\begin{abstract}
Monogamy is rare in fishes and is usually associated with elaborate parental care. When parental care is present in fishes, it is usually the male that is responsible, and it is believed that there is a relationship between the high energetic investment and the certainty of paternity (except in the case of sneaker males). Osteoglossum bicirrhosum is considered a monogamous fish, and has particular behavioral traits that permit the study of mating systems and parental care, such as male mouthbrooding. We investigated the genetic relationships of males with the broods found in their oral cavities in Osteoglossum samples collected in a natural environment in the lower Purus river basin, Amazonas, Brazil. Fourteen broods were analyzed for parentage (268 young and 14 adult males) using eight microsatellite loci. The results indicate that eleven broods show a monogamous system. In one brood, however, approximately $50 \%$ of the young were genetically compatible with being offspring of another male, and in another two broods, none of the subsampled young were compatible with the genotypes of the brooding male. The result of this first brood may be explained by the extra-parental contribution of a sneaker male, whereas cooperative parental care may explain the result in the other two broods.
\end{abstract}

Monogamia é rara em peixes e está geralmente associada a cuidado parental elaborado. Quando cuidado parental está presente em peixes, usualmente o macho é responsável, e acredita-se que exista uma relação entre investimento energético elevado e a certeza da paternidade (exceto no caso de machos oportunistas). Osteoglossum bicirrhosum é considerado monogâmico e possui determinadas características comportamentais que permitem o estudo de sistemas de acasalamento e cuidado parental, como incubação bucal dos ovos e filhotes pelos machos. Quatorze ninhadas (268 filhotes e 14 machos adultos) foram coletadas em ambiente natural na bacia do baixo rio Purus, Amazonas, Brasil e analisadas para parentesco utilizando oito loci de microssatélites. Os resultados sugeriram, para onze ninhadas, um sistema de acasalamento monogâmico. Em uma ninhada, no entanto, cerca de $50 \%$ dos jovens eram geneticamente compatíveis como sendo descendentes de outro macho, e em outras duas ninhadas nenhum dos filhotes amostrados eram filhos dos machos que estavam realizando o cuidado. $\mathrm{O}$ resultado da primeira ninhada pode ser explicado pela contribuição extra-par de um macho oportunista, enquanto que o cuidado parental cooperativo pode explicar os resultados nas outras duas ninhadas.

Key-words: Cooperative parental care, Microsatellite, Monogamy, Mouthbrooding.

\section{Introduction}

Fishes have a wide diversity of reproductive traits, which make them an interesting group in which to study the evolution of mating systems (DeWoody et al., 2000). Within fishes, the mating system seems to be strongly connected to the type of parental care (Perrone \& Zaret, 1979). Monogamy, a rare mating system among fishes, is mainly related to elaborate and prolonged reproduction, in which bi-parental care becomes a necessity (Trivers, 1972).

Blumer (1982) considered that 89 families of fishes perform some kind of parental care, and in the majority of

\footnotetext{
${ }^{1}$ Instituto Nacional de Pesquisas da Amazônia, Coordenação de Biodiversidade. Avenida André Araújo, 2936, CP 478, Aleixo. 69011-970 Manaus, AM, Brazil. juliatovarv@gmail.com (JTV); jzuanon3@gmail.com(JZ)

${ }_{2}^{2}$ Instituto Piagaçu. Rua Uz, 08, Quadra Z, Conjunto Morada do Sol, 69060-095 Manaus, AM, Brazil. zecarabello@me.com ${ }^{3}$ Laboratório de Evolução e Genética Animal, Universidade Federal do Amazonas. Avenida General Rodrigo Octávio Jordão Ramos, 3000, Câmpus Universitário, Coroado I, Manaus, AM, Brazil. izeni_farias@ufam.edu.br
} 
these species this role of a caregiver is played by the male. Trivers (1972) suggested that paternal investment in parental care is directly related to the certainty of paternity, that is, the more the male is in doubt of its paternity, the less will be its willingness to invest in the parental care, although this concept is not universally accepted (Werren et al., 1980; Bouwman et al., 2005). A number of studies have shown this phenomenon in birds (e.g., Moller \& Cuervo, 2000; Peterson et al., 2001), fishes (e.g., Neff, 2003; Neff \& Gross, 2001), and invertebrates (Hunt \& Simmons, 2002). However, Ah-King et al., (2004) point out that on the contrary of what would be expected, for some species of fish where the certainty of paternity within the brood - and subsequently the proportion of true paternity - is reduced due to the occurrence of sneaker males, there is no decrease in the investment in parental care.

The silver arowana Osteoglossum bicirrhosum (Cuvier, 1829) occurs in the lowland and flooded forests on the Amazon basin and is heavily exploited by humans at two different life stages: as an adult for food, and as young for the ornamental fish trade (an illegal activity in Brazil). The illegality of this fishing makes it difficult to estimate the impact of this exploitation of the species. The silver arowana presents some characteristics that make it interesting for mating system studies: the arowana occupies the upper layer of the water column, which allows behavioral observations; and parental care is provided by the males through mouthbrooding (Goulding, 1980), which lasts for nearly six weeks (Queiroz, 2008). When the fry are free-swimming, they leave the male's mouth, returning to the bucal cavity after satiation or when threatened (Queiroz, 2008). The mating system of the silver arowana is believed to be serially monogamous, with the formation of couples in every reproductive season (Queiroz, 2008), although no conclusive studies have yet demonstrated this. However, among fishes, monogamy is only expected in species with oral incubation of fry, when the protection of the offspring by both parents is important to the offspring's survival (Wittenberger \& Tilson, 1980). This is not the case in the arowana.

Another reproductive feature of the silver arowana is the formation of male aggregations during the parental care phase, locally known as "choqueiros" or "hatcheries" (Rabello Neto, 2008). Although fishermen in the Amazon usually mention their occurrence, the characteristics of these aggregations are still not properly understood. According to the fishermen, fishing for the ornamental fish market often targets these hatcheries.

Gregarious behavior during reproduction and parental care have been described for other vertebrates. The most common involves reproductive and non-reproductive individuals, the last acting as helpers in fish (Wisenden, 1999). Another type of aggregation is the "nursery", in which the young individuals are kept clustered under the care of some adult individuals, while the others forage (with these roles being switched among adults over time). This behavior is well described for several species of birds (e.g., Pettingill Jr., 1960; Kirkwood \& Robertson, 1997) and pinniped mammals (Cassini, 1999). Among silver arowanas, the possible functions of male aggregations during the parental care phase are not known. There is no information about a mixing of young from different male parents, which could indicate cooperative parental care. Also, little is known about the familial relationships among the fry that compose a brood, and their relationship to the adult males that carry them. In any event, the formation of hatcheries suggests the existence of social relationships among adult arowanas. Taking into account the characteristics of formation of couples, the high investment in large oocytes and the parental care, we hypothesize that the silver arowana is serially monogamous, and that all the fry of a given brood are siblings. The objective of this study was, thus, to identify the mating system of the silver arowana $O$. bicirrhosum and the genetic relationships among males and the respective broods carried in their mouth cavity by using microsatellite, highly polymorphic DNA markers, very useful for parentage studies (Queller et al., 1993; DeWoody, 2005). This study may help clarify issues related to the mating system traits and parental care of the silver arowana. Also, it can contribute to the species' handling practices, as both a food source, and for the ornamental fish trade (Lima \& Prang, 2008).

\section{Material and Methods}

\section{Study site}

Field collections were made in floodplain lakes of the "Reserva de Desenvolvimento Sustentável Piagaçu-Purus" (RDSPP), located at the lower Purus river, state of Amazonas, Brazil, where fishing resources are intensively exploited. In average, $48 \%$ of the fishes caught with fishing nets and disembarked in Manaus, the largest city of the Brazilian Amazon, from 1994 to 2004 are from the Purus River basin (Fernandes et al., 2009). The RDSPP was created in 2003, and its landscape is heterogeneous, with several floodplains (varzea) and large areas of non-flooded forest (terra firme forest). The floodplain lakes constitute $44 \%$ of the reserve's area, and are partially covered by dense aquatic macrophytes (Instituto Piagaçu, 2010). The current study was performed in the floodplain area of RDSPP's North Region, sector Caua/ Cuiuanã. From 1990 to 2003, there was significant exploitation of arowana fry for ornamental purposes.

\section{Data Collection}

Collections were made in the Ambé $\left(04^{\circ} 11^{\prime} 14.8^{\prime \prime} \mathrm{S}\right.$ $\left.61^{\circ} 51^{\prime} 20.2^{\prime \prime} \mathrm{W}\right)$, Preto $\left(04^{\circ} 11^{\prime} 12.0^{\prime \prime} \mathrm{S} 61^{\circ} 57^{\prime} 56.4^{\prime \prime} \mathrm{W}\right)$, and Leitão $\left(04^{\circ} 15^{\prime} 11.2^{\prime \prime} \mathrm{S} 61^{\circ} 47^{\prime} 52.0^{\prime \prime} \mathrm{W}\right)$ lakes, during the flooded 
seasons (February) of 2011 and 2012. These large lakes overflowed into flooded areas in the wet season, are partially covered by macrophytes, and were indicated by the fishermen as the ones with the highest density of arowana. The lakes were surveyed using the "night focusing" technique: canoes and flashlights being used in an intensive search for individuals providing parental care. When the adult fishes were seen with eggs or fry (identified by the expanded mouth cavity), they were collected with a trident, an instrument similar to a spear. Every fish collected was inspected for the presence of offspring (eggs, larvae, or fry) in the mouth cavity, which were then collected into a plastic bag. One of the chin barbels of each male was collected, and stored together with the offspring. The samples were conserved in alcohol $96 \%$ for further molecular analysis.

\section{Collection of genetic data}

A sample of tissue was taken from every individual (larva/ young and barbel of adult males) and stored at $-20^{\circ} \mathrm{C}$. DNA was extracted using the cetyltrimethylammoniumbromide (CTAB) protocol (Doyle \& Doyle, 1987) with approximately $100 \mathrm{mg}$ of tissue used for each extraction. The concentration of the extracted DNA was quantified with NanoDrop 2000c Spectrophotometer and samples were standardized to a final concentration of 20 to $30 \mathrm{ng} / \mu \mathrm{l}$.

Eight microsatellite loci developed by Silva et al. (2009) for Osteoglossum bicirrhosum - Ob_B11, Ob_C01, Ob_D09, Ob_F09, Ob_H09, Ob_C04, Ob_A01 and Ob_G11 - were selected for the analyses. The genotyping was carried out according to the method described by Schuelke (2000). PCR reactions for all primers pairs were carried out in a final volume of $12.5 \mu \mathrm{L}$ containing $4.95 \mu \mathrm{L}$ of $\mathrm{ddH}_{2} \mathrm{O}, 1.5 \mu \mathrm{L}$ of $\mathrm{MgCl}(25 \mathrm{mM}), 1.5 \mu \mathrm{L}$ of dNTP $(10 \mathrm{mM}), 1.25 \mu \mathrm{L}$ of $10 \mathrm{x}$ PCR buffer (100 mM Tris- $\mathrm{HCl}, 500 \mathrm{mM} \mathrm{KCl}), 0.5 \mathrm{X} \mu \mathrm{L}$ of forward primer with M13(-21) 5 tail $(2.0 \mu \mathrm{M}), 1.0 \mu \mathrm{L}$ of reverse primer $(2.0 \mu \mathrm{M}), 0.5 \mu \mathrm{L}$ of fluorescently-labeled M13(-21) primer $(2.0 \mu \mathrm{M}), 0.3 \mu \mathrm{L}$ of Taq DNA Polymerase $(5 \mathrm{U} / \mu \mathrm{L})$, and $1 \mu \mathrm{L}$ of DNA. PCRs were run in a Veriti thermocycler and had two main steps: an initial denaturation step $\left(94^{\circ} \mathrm{C}\right.$, $1 \mathrm{~min}$.) followed by $25 \mathrm{cycles}$ of $50 \mathrm{sec}$. at $94^{\circ} \mathrm{C}, 20 \mathrm{sec}$. at primer-specific annealing temperature (according to Silva et al., 2009), $20 \mathrm{sec}$ at $72^{\circ} \mathrm{C}$; followed by 20 cycles of $20 \mathrm{sec}$. at $94^{\circ} \mathrm{C}, 20 \mathrm{sec}$. at $50^{\circ} \mathrm{C}, 20 \mathrm{sec}$. at $72^{\circ} \mathrm{C}$, and a final extension step for 30 minutes at $72^{\circ} \mathrm{C}$. If necessary the PCR products were diluted, and the size marker ROX pUC-19, modified from DeWoody et al., (2004), was added to determine sizes of observed alleles. Genotyping of the amplified DNA was determined in an ABI 3130xl automatic sequencer, and the alleles observed in each individual were analyzed using the GeneMapper v.4.0 program.

\section{Data Analysis}

With the software Genalex v6.41 (Peakall \& Smouse, 2006), the probabilities of identity and parental exclusion were calculated for every brood, and show how informative each group of loci are. The probability of identity provides an estimate of the likelihood of two non-related individuals, collected from the same population, to have the same multilocus genotype. The probability of parental exclusion considers the ability of markers to exclude a random male as a father. The closer the probability of identity is to zero, the more informative the group of loci are. On the other hand, the probability of exclusion should be closer to one.

For the verification of multiple paternity, a manual counting of allele number was made for every locus. The occurrence of more than four alleles at a locus indicates an instance of multiple paternity. The occurrence of adult males' alleles in fry's genotype was also verified. The division of the broods into sibling groups was made with the software Kinalyzer (Ashley et al., 2009). It uses an optimization approach combined to create sibling groups (based on Mendelian properties), searching a minimum amount of possible groups (Jones et al., 2010). For the reconstruction of parental genotypes and an estimating of the number of fathers contributing in every brood, we used the software Gerud 2.0 (Jones, 2005). This software reconstructs the parental genotypes of an offspring containing only siblings or half-siblings, without the need of knowing one parental genotype. Thus, it uses an algorithm which searches for all possible parental genotypes of a brood and finds a minimum set of genotypes required to explain the matrix of the fry's genotypes (Jones et al., 2010). The analysis in Kinalyzer and Gerud 2.0 were made only with the genotypes of the fry. Later, the parental genotypes resulting from the Gerud 2.0 analysis were compared to the genotypes directly obtained from the tissue samples of the males.

\section{Results}

Fourteen broods were analyzed with the number of fry varying from 57 to 146 between broods. Sixteen to 20 young individuals randomly selected from each brood, corresponding to $13-35 \%$ representation, were used for the analyses, in addition to the 14 adult males; in total 283 individuals were analyzed (Table 1). The average size of the fry in each brood varied from $1.0 \mathrm{~cm}$ (embryonic phase) to $6.8 \mathrm{~cm}$ (fingerling), and all the individuals collected in the same brood were in the same stage of development. The number of alleles in each one of the eight microsatellite loci varied from two to seven, with an average of $4.5 \pm 1.6$ alleles per locus. The probabilities of identity and exclusion of the locus set in every brood varied from 0.015 (N9) to 0.175 (N126), and 0.689 (N126) to 0.972 (N9) respectively (Table 1$)$. In six broods (43\%), 
Table 1. Number of alleles per loci, per brood. *Non-monogamous broods. PI $=$ Probability of Identity. PE $=$ Probability of Exclusion. $\mathrm{N}=$ Number of fry per brood. $\mathrm{n}=$ number of fry analyzed per brood. $\mathrm{N}^{\circ}$ loci $=$ Number of microsatellite loci used per brood. The number of sibling groups estimated with the use of the softwares Gerud 2.0 and Kinalyzer. PI and PE indicate that the number of loci is very informative to six of the fourteen broods (in bold).

\begin{tabular}{|c|c|c|c|c|c|c|c|c|c|c|c|c|c|c|c|}
\hline Brood & $\begin{array}{l}\mathrm{Ob}_{-} \\
\mathrm{B} 11\end{array}$ & $\begin{array}{l}\mathrm{Ob}_{-} \\
\mathrm{C} 01\end{array}$ & $\begin{array}{l}\mathrm{Ob}_{-} \\
\text {F09 }\end{array}$ & $\begin{array}{l}\mathrm{Ob}_{-} \\
\mathrm{A} 01\end{array}$ & $\begin{array}{l}\mathrm{Ob}_{-} \\
\mathrm{G} 11\end{array}$ & $\begin{array}{l}\mathrm{Ob}_{-} \\
\mathrm{H} 09\end{array}$ & $\begin{array}{l}\mathrm{Ob}_{-} \\
\mathrm{C} 04\end{array}$ & $\begin{array}{l}\mathrm{Ob}_{-} \\
\mathrm{D} 09\end{array}$ & PI & $\mathrm{PE}$ & $\mathrm{N}$ & $\mathrm{n}$ & $\mathrm{N}^{\circ}$ loci & Kinalyzer & $\begin{array}{c}\text { Gerud } \\
2.0\end{array}$ \\
\hline N9 & 4 & 3 & 2 & 3 & 2 & 2 & 2 & 3 & 0.015 & 0.972 & 57 & 19 & 7 & 1 & 1 \\
\hline N10* & 3 & 2 & 2 & 1 & 2 & 3 & 2 & - & 0.028 & 0.954 & 124 & 20 & 6 & 3 & 3 \\
\hline N11 & 3 & 3 & 3 & 1 & 3 & 3 & 2 & - & 0.018 & 0.971 & 136 & 20 & 6 & 1 & 1 \\
\hline N12 & 3 & 3 & 2 & 1 & 2 & 2 & 2 & - & 0.058 & 0.902 & 74 & 20 & 7 & 1 & 1 \\
\hline N13 & 1 & 2 & 2 & 2 & 2 & 2 & - & - & 0.120 & 0.759 & 69 & 20 & 6 & 1 & 1 \\
\hline N14* & 3 & 2 & 2 & 2 & 2 & 3 & 2 & 3 & 0.021 & 0.946 & 57 & 20 & 6 & 2 & 2 \\
\hline N15 & 2 & 2 & 1 & 1 & 2 & 2 & 2 & - & 0.162 & 0.722 & 73 & 17 & 7 & 1 & 1 \\
\hline N16 & 2 & 2 & 2 & 2 & 2 & - & - & 2 & 0.100 & 0.800 & 64 & 18 & 6 & 1 & 1 \\
\hline N32* & 4 & 2 & 3 & 1 & 1 & 3 & 2 & 3 & 0.028 & 0.958 & 79 & 20 & 8 & 2 & 2 \\
\hline N33 & 3 & 3 & 1 & 1 & 2 & - & 2 & 3 & 0.068 & 0.886 & 146 & 19 & 7 & 1 & 1 \\
\hline N34 & 4 & 2 & 2 & 1 & 2 & - & - & 2 & 0.087 & 0.843 & 101 & 16 & 6 & 1 & 1 \\
\hline N126 & 2 & 2 & 2 & 1 & 2 & - & - & - & 0.175 & 0.689 & 91 & 20 & 5 & 1 & 1 \\
\hline N127 & 2 & 2 & 2 & 1 & 3 & - & - & - & 0.019 & 0.777 & 103 & 20 & 5 & 1 & 1 \\
\hline N134 & 4 & 2 & 2 & 1 & 1 & - & - & - & 0.159 & 0.797 & 100 & 20 & 4 & 1 & 1 \\
\hline Total & 5 & 6 & 3 & 4 & 4 & 5 & 2 & 7 & & & 1274 & 269 & & & \\
\hline
\end{tabular}

the probability of exclusion was higher than 0.90 , which indicates the set of microsatellites used is highly informative for those broods. The other broods - where the probability of exclusion was lower - were also used in the analysis, but the occurrence of multiple paternity events can be underestimated in these broods.

\section{Paternity analysis}

The manual check with allele counting per locus in every brood did not show any indication of multiple paternity, considering standard Mendelian inheritance. However, when the presence of the adult male's alleles was verified in the broods, male alleles were not detected in three: in the brood $\mathrm{N} 10$ ( $\mathrm{N}=124$ fry, 20 analyzed), some fry did not have any shared allele with their respective adult male (one fry for the locus Ob_B11 and nine for the locus $\mathrm{Ob} \_\mathrm{H} 09$, representing $45 \%$ of the brood). In the brood N14 ( $=57,20$ analyzed), the difference was observed in six fry for the locus Ob_H09 (30\%). In the brood N32 ( $=79,20$ analyzed), three fry for locus Ob_B11 and 12 fry for the locus Ob_H09 did not have alleles compatible with the genotype of the adult male that carried that brood $(65 \%)$. In the remaining broods, the results indicated the participation of a single male and female in the fertilization, which represents a monogamous mating system.

The analysis of sibling group formation by combined optimization performed in the software Kinalyzer, indicated the occurrence of three sibling groups in the brood N10, and two groups in the broods N14 and N32 (Table 1). The division of the broods in sibling groups, by using both Gerud 2.0 and Kinalyzer indicated that $78.6 \%$ of the broods being sired by one male, $14.2 \%$ by two males and $7.2 \%$ by three males (Table 1).

The comparison of parental genotypes - reconstructed by Gerud 2.0 using the genotype matrix of the offspring - with the genotypes of males collected along with the broods, showed incompatibility in two broods (N10 and N32), indicating that males were not the genetic fathers (paternal exclusion) of any of the offspring analyzed in that broods. In the brood N14, almost half of the fry (48\%) showed genotypes compatible to the paternal male, while the other half is compatible to the fertilization of another male.

\section{Discussion}

The results indicate that most of the broods analyzed (78.6\%, 11 of 14$)$ were fertilized in a monogamous mating system, involving only one male and one female. This kind of mating system seems to be an exception in most animal groups (e.g., Kleiman, 1977; Taylor et al., 2003). Nevertheless, our results showed exceptions: three of 14 broods $(21.4 \%)$ indicated the occurrence of more than one male participating in the fertilization of the offspring. Since the first application of molecular techniques to the study of mating systems, it was demonstrated that several socially monogamous species are not genetically monogamous (e.g., Goossens et al., 1998; Sefc et al., 2008; Liebgold et al., 2006; Ophir et al., 2008). 
Genetic studies compiled by DeWoody \& Avise (2001) have documented that on average, nest-guarding adults parented about $70-95 \%$ of their custodial offspring, and approximately one-third of the nests were cuckolded to some extent. Furthermore, nearly $10 \%$ of the assayed nests contained offspring tended by foster fathers either because of nest takeover or egg thievery.

The brood N14 - where close to half of the brood seems to be comprised by fry from the parental male and the other half by another - can be considered a typical case of multiple paternity. Considering the behavior of couple formation, probably this extra-pair fertilization occurred due to the interference of a sneaker male. This male can take advantage of the moments in which the couple is involved in oviposition and fertilization to deposit its spermatozoa and fertilize some oocytes, leaving the eggs to be cared for by the other male. This behavior has been described in the Gasterosteidae (Largiàder et al., 2001), Cichlidae (Ota et al., 2012) and Gobiidae (Mobley et al., 2009). The role of paternal care can evolve in species with higher certainty of paternity, even in the occurrence of opportunist males (Ah-King et al., 2004). Accordingly, it seems like the value of the care is so high that the strategy (prolonged parental care, which requires a greater energy expenditure) persists even under the possibility of having fry from other males in the brood.

The males considered sneakers can act in different forms (Taborsky, 1994). It is possible that, in the case of the arowana, the females choose the bigger males, since larger individuals have larger mouth cavities (and more space to shelter the broods) and better physical condition to defend the offspring (Queiroz, 2008). In that sense, smaller young males can use the tactic of a sneaker as a way to find reproductive success immediately upon maturity as described in several species of fishes (e.g., Ota et al., 2012; Largiadèr et al., 2001; Jones et al., 2001; Gross \& Charnov, 1980).

The most intriguing result found in the current study was the complete lack of a genetic relationship between males and fry in two of the broods analyzed (N10 and N32). In the current study we identified some possibilities to explain this occurrence.

One hypothesis is based on the occurrence of cooperative parental care, through the mixing of broods. Behaviors of cooperative care are considered rare in fishes (Taborsky, 1994). The combination of broods can happen when fry leave the mouth cavity of one male to feed, and when they return, they enter the mouth of another male. This is especially probable in species that do not have stable territories (Taborsky, 1994), such as arowana. Considering occurence of social hatcheries, this is a plausible hypothesis. In addition, it was noted that in these two broods, the offspring were in an advanced stage of development. This means they would be leaving the protection of the male's mouth for feeding purposes. Although this situation is a simple occurrence, the result (energetic investment with parental care of fry from other individuals) would be evolutionarily disadvantageous. If that is the case, an evolutionary stable strategy would involve cooperative care, where individuals of an aggregation of males would collectively care for the fry (complete or partial broods). In this case, the mixing of fry, or even the guard of complete broods from other fathers, would not be strongly disadvantageous for the individual since the other male would be performing the same role with his brood.

It is known that in the asian arowana (Scleropages formosus), the mating form and parental care is similar to the silver arowana's, with the formation of couples and mouth-brooding performed by males (Rowley et al., 2008; Suleiman, 2003). This suggests this behavior could have evolved in an ancestor of the group, taking into account the geographical distribution of the family and the persistence of this lineage (Kumazawa \& Nishida, 2000). In the species Arapaima gigas, the pirarucu, which belongs to the same order as the silver arowana and has a sympatric occurrence, indications of multiple paternity were also found (Farias et al., in prep.). Specific features, such as the formation of aggregations for the parental care have yet to be investigated in other species of osteoglossiform.

Among the samples analyzed in the current study, it is possible to state, with little doubt, the occurrence of multiple paternity in one brood only (N14), where the fry were not sufficiently developed to swim freely. In eleven broods, the strongest indication is that the mating had involved only one couple. The analysis of broods N10 and N32 can demonstrate a type of cooperative care. However, the occurrence of multiple paternity events and cooperative care may be underestimated, since the collections were not made in hatcheries, and a higher density of individuals can influence the occurrence of these events, as suggested by Mackiewicz et al. (2002) for Lepomis.

We conclude that the mating system of the silver arowana can generally be considered as being serially monogamous, but also with a reasonable proportion of fertilizations by additional males, possibly not made by the female's choice, but by sneaker males. Finally, the occurrence of cooperative care by males of $O$. bicirrhosum is possible, but more studies of natural history and the behavior of the species are required to clarify this issue. Parentage analysis using microsatellites in species with male mouthbrooders are rare (Coleman \& Jones, 2011). Therefore, we encourage studies using genetics, natural history and behavior to generate more information about cooperative care, mating systems and paternity certainty, that still remain unclear in several neotropical piscine species.

\section{Acknowledgments}

This research was supported by grants from $\mathrm{CNPq}$ (process 575603/2008-9 and 557004/2009-8) to IPF. We thank IDSM/ IPI_1.4.2011_Aruanãs project through the Term of Technical 
Cooperation between the Institute of Sustainable Development Mamirauá - IDSM and Piagaçu Institute - IPi for financial and logistical support. JZ and IPF receive productivity scholarship of CNPq (process 307464/2009-1 and 302125/2009-4, respectively). This study was developed from the master degree paper of J. T. Verba, in the "Programa de Pós-Graduação em Ecologia, INPA, with a study scholarship of CNPq.

\section{Literature Cited}

Ah-King, M., C. Kvarnemo \& B. S. Tullberg. 2004. The influence of territoriality and mating system on the evolution of male care: a phylogenetic study on fish. Journal of Evolutionary Biology, 18: 371-382.

Ashley, M. V., I. C. Caballero, W. Chaovalitwongse, B. Dasgupta, P. Govindan, S. I. Sheikh \& T. Y. Berger-Wolf. 2009. KINALYZER, a computer program for reconstructing sibling groups. Molecular Ecology Resources, 9: 1127-1131.

Blumer, L. S. 1982. A bibliography and categorization of bony fishes exhibiting parental care. Zoological Journal of the Linnean Society, 75: 1-22.

Bouwman, K. M., C. M. Lessells \& J. Komdeur. 2005. Male reed buntings do not adjust parental effort in relation to extrapair paternity. Behavioral Ecology, 16: 499-506.

Cassini, M. H. 1999. The evolution of reproductive systems in pinnipeds. Behavioral Ecology, 10: 612-616.

Coleman, S. W. \& A. G. Jones. 2011. Patterns of multiple paternity and maternity in fishes. Biological Journal of the Linnean Society, 103: 735-760.

DeWoody, J. A., D. E. Fletcher, S. D. Wilkins, W. S. Nelson \& J. C. Avise. 2000. Genetic monogamy and biparental care in an externally fertilizing fish, the largemouth bass (Micropterus salmoides). Proceedings of the Royal Society B, 267: 2431-2437.

DeWoody, J. A., J. Schupp, L. Kenefic, J. Busch, L. Murfitt \& P. Keim. 2004. Universal method for producing ROX-labeled size standards suitable for automated genotyping. Biotechniques, 37: 348-352.

DeWoody, J. A. 2005. Molecular approaches to the study of parentage, relatedness, and fitness: practical applications for wild animals. Journal of Wildlife Management, 69: 1400-1418.

Doyle, J. J. \& J. L. Doyle. 1987. A rapid DNA isolation procedure for small quantities of fresh leaf tissue. Phytochemistry, 19: 11-15.

Fernandes, V. L. A., R. N. Vicentini \& V. S. Batista. 2009. Caracterização do uso de malhadeiras pela frota pesqueira que desembarca em Manaus e Manacapuru, Amazonas. Acta Amazonica. 39: 405-414.

Goossens, B., L. Graziani, L. P. Waits, E. Farand, S. Magnolon, J. Coulon, M. C. Bel, P. Taberlet \& D. Allainé. 1998. Extrapair paternity in the monogamous Alpine marmot revealed by nuclear DNA microsatellite analysis. Behavioral Ecology and Sociobiology, 43: 281-288.

Goulding, M. 1980. The fishes and the forest, explorations in Amazonian natural history. Berkeley, University of California Press.

Gross, M. R. \& E. L. Charnov. 1980. Alternative male life histories in bluegill sunfish. Proceedings of the National Academy of Sciences, 77: 6937-6940.

Hunt, J. \& L. W. Simmons. 2002. Confidence of paternity and paternal care: covariation revealed through the experimental manipulation of the mating system in the beetle Onthophagus taurus. Journal of Evolutionary Biology, 15: 784-795.

Instituto Piagaçu. 2010. Plano de Gestão Reserva de Desenvolvimento
Sustentável Piagaçu-Purus - Vol I e II: Versão para consulta pública. Manaus.

Jones, A. G., D. Walker, C. Kvarnemo, K. Lindström \& J. C. Avise. 2001. How cuckoldry can decrease the opportunity for sexual selection: Data and theory from a genetic parentage analysis of the sand goby, Pomatoschistus minutus. Proceedings of the National Academy of Sciences, 98: 9151-9156.

Jones, A. G. 2005. GERUD 2.0: a computer program for the reconstruction of parental genotypes from half-sib progeny arrays with known and unknown parents. Molecular Ecology Notes, 5: 708-711.

Jones, A. G., C. M. Small, K. A. Paczolt \& N. L. Ratterman. 2010. A practical guide to methods of parentage analysis. Molecular Ecology Resources, 10: 6-30.

Kirkwood, R. \& G. Robertson. 1997. Seasonal change in the foraging ecology of emperor penguins on the Mawson Coast, Antarctica. Marine Ecology Progress Series. 156: 205-223.

Kleiman, D. G. 1977. Monogamy in mammals. The Quarterly Review of Biology, 52: 39-69.

Kumazawa, Y. \& M. Nishida. 2000. Molecular phylogeny of Osteoglossoids: A new model for Gondwanian origin and plate tectonic transportation of the Asian Arowana. Molecular Biology and Evolution, 17: 1869-1878.

Largiadèr, C. R., V. Fries \& T. C. M. Bakker. 2001. Genetic analysis of sneaking and egg-thievery in a natural population of the three-spined stickleback (Gasterosteus aculeatus L.). Heredity, 86: 459-468.

Liebgold, E. B., P. R. Cabe, R. G. Jaeger \& P. L. Leberg. 2006. Multiple paternity in a salamander with socially monogamous behaviour. Molecular Ecology, 15: 4153-4160.

Lima, A. C. \& G. Prang. 2008. Demandas para o Manejo e Conservação do Aruanã Branco, Osteoglossum bicirrhosum (Cuvier, 1829), na Região do Médio Rio Solimões. Pp. 15-26. In: Queiroz, H. L. \& M. Camargo (Eds.). Biologia, conservação e manejo dos aruanãs na Amazônia brasileira. Tefé, Amazonas: IDSM.

Mackiewicz, M., D. E. Fletcher, S. D. Wilkins, J. A. DeWoody \& J. C. Avise. 2002. A genetic assessment of parentage in a natural population of dollar sunfish (Lepomis marginatus) based on microsatellite markers. Molecular Ecology, 11: 1877-1883.

Mobley, K. B., T. Amundsen, E. Forsgren, P. A. Svensson \& A. G. Jones. 2009. Multiple mating and a low incidence of cuckoldry for nest-holding males in the two-spotted goby, Gobiusculus flavescens. BMC Evolutionary Biology, 9: 6.

Moller, A. P. \& J. J. Cuervo. 2000. The evolution of paternity and paternal care in birds. Behavioral Ecology, 11: 472-485.

Neff, B. B. 2003. Decisions about parental care in response to perceived paternity. Nature, 422: 716-719.

Neff, B. D. \& M. R. Gross. 2001. Dynamic adjustment of parental care in response to perceived paternity. Proceedings of the Royal Society B, 268: 1559-1565.

Ophir, A. G., S. M. Phelps, A. B. Sorin \& J. O. Wolff. 2008. Social but not genetic monogamy is associated with greater breeding success in prairie voles. Animal Behaviour, 75: 1143-1154.

Ota, K., M. Aibara, M. Morita, S. Awata, M. Hori \& M. Kohda. 2012. Alternative reproductive tactics in the shell-brooding Lake Tanganyika cichlid Neolamprologus brevis. International Journal of Evolutionary Biology, 2012: 1-10.

Peakall, R. \& P. E. Smouse. 2006. GENALEX 6: genetic analysis in Excel. Population genetic software for teaching and research. Molecular Ecology Notes, 6: 288-295.

Perrone, Jr M. \& T. M. Zaret. 1979. Parental care patterns of fishes. The American Naturalist, 113: 351-361. 
Peterson, K. A.,K. J. Thusius, L. A. Whittingham \& P. O. Dunn. 2001. Allocation of male parental care in relation to paternity within and among broods of the Common Yellowthroat (Geothlypis trichas). Ethology, 107: 573-586.

Pettingill Jr, O. S. 1960. Crèche Behavior and Individual Recognition in a Colony of Rockhopper Penguins. The Wilson Bulletin, 72: 212-221.

Queiroz, H. L. 2008. Investimento parental e reprodução do aruanã branco, Osteoglossum bicirrhosum, na Reserva Mamirauá, Pp. 119-132. In: Queiroz, H. L. \& M. Camargo (Eds.). Biologia, conservação e manejo dos aruanãs na Amazônia brasileira. Tefé, Amazonas: IDSM.

Queller, D. C., J. E. Strassmann \& C. R. Hughes. 1993. Microsatellites and kinship. Trends in Ecology \& Evolution, 8: 285-288.

Rabello Neto, J. G. 2008. A exploração de filhotes de aruanã preto (Osteoglossum ferreirai) e do aruanã branco (Osteoglossum bicirrhosum) como peixes ornamentais no médio rio Negro. Pp. 27-40. In: Queiroz, H. L. \& M. Camargo (Eds.). Biologia, conservação e manejo dos aruanãs na Amazônia brasileira. Tefé, Amazonas: IDSM.

Rowley, J. J. L., D. A. Emmett \& S. Voen. 2008. Harvest, trade and conservation of the Asian arowana Scleropages formosus in Cambodia. Aquatic Conservation: Marine and Freshwater Ecosystems, 18: 1255-1262.

Schuelke, M. 2000. An economic method for the fluorescent labeling of PCR fragments. Nature Biotechnology, 18: 233-234.

Sefc, K. M., K. Mattersdorfer, C. Sturmbauer \& S. Koblmüller. 2008. High frequency of multiple paternity in broods of a socially monogamous cichlid fish with biparental nest defence. Molecular Ecology, 17:2531-2543.
Silva, T. J., T. Hrbek \& I. P.Farias. 2009. Microsatellite markers for the silver arowana (Osteoglossum bicirrhosum, Osteoglossidae, Osteoglossiformes). Molecular Ecology Resources, 9: 1019-1022.

Suleiman, M. Z. 2003. Breeding technique of Malaysian golden arowana, Scleropages formosus in concrete tanks. Aquaculture Asia, 8: 11-13.

Taborsky, M. 1994. Sneakers, satellites, and helpers: parasitic and cooperative behavior in fish reproduction. Pp.1-100. In: Advances in the Study of Behavior, 23.

Taylor, M. I., J. I. Morley, C. Rico \& S. Balshine. 2003. Evidence for genetic monogamy and female-biased dispersal in the biparental mouthbrooding cichlid Eretmodus cyanostictus from Lake Tanganyika. Molecular Ecology, 12: 3173-3177.

Trivers, R. L. 1972. Parental investment and sexual selection. Pp. 136-179. In: Campbell B, editors. Sexual Selection and the Descent of Man. Chicago.

Werren, J. H., M. R. Gross \& R. Shine. 1980. Paternity and the evolution of male parental care. Journal of Theoretical Biology, 82: 619-631.

Wisenden, B. D. 1999. Alloparental care in fishes. Reviews in Fish Biology and Fisheries, 9: 45-70.

Wittenberger, J. F. \& R. L. Tilson. 1980. The evolution of monogamy: Hypotheses and evidence. Annual Review of Ecology and Systematics, 11: 197-232.

Submitted March 24, 2013

Accepted November 17, 2013 by Claudio Oliveira

Published March 31, 2014 